\title{
Profile of Fatty Acid and Polycyclic Aromatic Hydrocarbons Smoked Pokea Clam (Batissa violacea celebensis Martens 1897) Produced in North Konawe District, South East Sulawesi
}

\author{
Kobajashi Togo Isamu ${ }^{1, *}$, Ahmad Mustafa ${ }^{2}$, Fajriah $^{3}$, Roslindah Daeng Siang ${ }^{4}$ \\ ${ }^{I}$ Department of Fisheries Product Technology, University of Halu Oleo, Kendari, Indonesia \\ ${ }^{2}$ Department of Fisheries Capture, University of Halu Oleo, Kendari, Indonesia \\ ${ }^{3}$ Department. of Fisheries Resources, Utility University of Muhammadiyah Kendari, Kendari, Indonesia \\ ${ }^{4}$ Dept. of Fisheries Agribussiness, University of Halu Oleo, Kendari, Indonesia \\ *)Corresponden Author, e-mail: kobajashi.tisamu@yahoo.com
}

\begin{abstract}
Pokea clam (Batissa violacea celebensis Martens 1897) is one of the endemic species in Southeast Sulawesi, which is much fave by local people as one of the daily favorite food menus, and one form of processing is by smoking. However, research on the profile of fatty acids and PAH compounds in smoked pokea clam has not been conducted, so information about these parameters is not yet available. The method used in this research is descriptive, where samples of smoked pokea clam produced from North Konawe District, were analyzed in terms of fatty acid profiles and PAH compounds, with sampling 3 times for 3 consecutive days. The results of the analysis of fatty acids obtained as many as 36 types of fatty acids, with a relative percent range of 0.001 to 98.539. While 5 types of PAH were detected, namely Naphtalene $0.10 \mathrm{ppm}$; Acenaphthene $0.05 \mathrm{ppm}$; Phenentrene 0.03 ppm; Fluorantene 0.08 ppm and Pyrene 11.98 ppm.
\end{abstract}

Keywords: Batissa, smoking, fatty acid, PAHs

\section{INTRODUCTION}

Several types of mollusks are potential fisheries commodities to be developed and are very promising as candidates for sources of new bioactive compounds for various biotechnological applications. Bivalvia and gastropods are a type of mollusk that are abundant in tropical waters and are a good source of animal protein at relatively low prices. Bioactive compounds found in mollusks are identified as essential peptides, depsipeptides, sesquiterpenes, squalene, terpenes, polypropionates, nitrogen compounds, macrolides, prostaglandins and fatty acid derivatives, other compounds and alkaloids; all have certain types of activities [1]; [2]. Pokea clam (Batissa violacea celebensis Marten 1897) are a bivalvia of the Corbiculidae Family found in the Pohara River Konawe District, Sulawesi. In their habitat, Pokea clam inhabit the bottom of the waters with sandy substrate texture. These clam also like waters with strong currents and live in groups as a form of adaptation [3].

Smoking of foodstuffs, especially fish and other fishery products (one of which is a clam), is one of the many traditional processing technologies carried out for years traditionally. Smoking can be defined as the process of penetration of volatile compounds in products produced from the burning of wood or similar materials, which are noted to produce products with specific taste and aroma, long shelf life due to anti-bacterial activity, inhibiting enzymatic activity in the product so that it can affect the quality of smoked products [10].

Several studies have been carried out to observe the smoking process of the quality of fish or smoked shellfish in different types of fish and shellfish [4-10]. However, information about bioactive compounds as well as toxic compounds of PAHa smoke shellfish produced in North Konawe Regency, Southeast Sulawesi is not yet available, so this research is expected to provide new information about smoked pokea clam.

\section{METHODS}

Time and place

The research was carried out in June 2019, with the location of sampling is in Pu'uwanggudu Village, Asera District, Konawe Utara Regency. Analysis of fatty acid profiles and PAHs was carried out at the Integrated Research and Testing Laboratory (LPPT) of Gadjah Mada University Yogyakarta.

Material Used

The materials used include, for example, concentrated $\mathrm{HCl}$ (Sigma-Aldrich, 37\%); diethyl ether (Sigma-Aldrich, $\geq$ 99\%); petroleum ether (Sigma-Aldrich, 75\%); N2 gas sodium metalonic solution (Sigma-Aldrich); Boron trifluoride metanoate (Aldrich 13-15\% BF3); heptane (Sigma-Aldrich, 99\%); $\mathrm{NaCl}$ (Sigma-Aldrich, 99.5\%). 


\section{Research methods}

The research method used is descriptive method, which is testing the fatty acid profile using the Gas chromatography method with a flame ionization detector (FID) following the method [11] and PAH using the Gas chromatography (Agilent Technologies $6890 \mathrm{~N}$ ) method with a flame ionization detector (FID) following the method [12] on smoked poke shells smoked using cabinet smoking, with sampling three times. While the data were analyzed using Microsoft Excel.

\section{RESULTS AND DISCUSSION}

The results of the analysis of the fatty acid profiles are shown in Table 1 below,

The large number of undetectable PAHs can be caused by habitat from unpolluted fish [13] as well as smoke composition, type of wood / fuel used [14]. Variations in the level of contamination in fish can be influenced by several factors, namely fish species / species, eating habits, bioavailability of chemicals in food and water, as well as the physicochemical parameters of the aquatic environment [15]; [16]. The high fat content in fish also facilitates the increase of PAHs adsorption into fish / shellfish meat [9]. Research conducted [17] reported that the PAHs content was very diverse in various types of fish smoked using sawdust, firewood, charcoal and drying ovens.

Reported that the compound content of Acenaphthene, Phenentrene, Anthracene, and Fluorantene was higher in all samples studied, namely smoked tuna filet, smoked swordfish and smoked salmon [26]. According to [27], Acenaphthene, Phenentrene, Anthracene, and Fluorantene compounds are PAHs compounds that have two, three or four aromatic rings, with low molecular weight and do not include carcinogenic compounds, which compounds are more representative of their presence only in marine ecosystems. Whereas [28] states that PAHs containing four joined rings, for example benzo (a) anthracene and chrysene, are weak carcinogenic. While five or six combined polycyclic hydrocarbon rings, some of which are carcinogenic potential, such as benzo (b) fluoranthene, benzo (a) pyrene, and indeno (1,2,3-cd) pyrene.

The composition of fish oil fatty acids is very dependent on fish eating habits [18], fish species and their growth conditions [19]. In addition, differences in food processing methods (especially fish) can affect the quality of fatty acids in the product, as well as changes in fatty acid content between fresh fish and processed fish. Processing that is commonly done on fish is by cooking, smoked, canned, baked, baked and fried.

The results of this study did not identify any content of EPA and DHA. This can be caused by heat treatment in the fogging process. According to [24], unsaturated fatty acids are less resistant to heat, with instability that increases with saturation. Combined with oxygen, PUFA degradation occurs more rapidly and PUFA experiences a noticeable oxidative effect. Several other studies also reported similar results, including [4] who reported that the DHA content fell sharply by $86.46 \%$ or $104.79 \mathrm{mg} / 100 \mathrm{~g}$ during the fumigation process in milkfish. [21] also observed a decrease in EPA and DHA content in smoked sardines. While [25] determine the decrease in the content of EPA and DHA in smoke shells.

Table 1. The fatty acid profiles

\begin{tabular}{|c|c|}
\hline Fatty Acid & $\begin{array}{c}\text { Relative Percentage } \\
(\%) \pm \text { SD }\end{array}$ \\
\hline Caproic acid & $0.009 \pm 0.006$ \\
\hline Lauric acid & $0.005 \pm 0.003$ \\
\hline Tridecanoic acid & $0.027 \pm 0.041$ \\
\hline Miristic acid & $0.006 \pm 0.007$ \\
\hline Pentadecanoic acid & $0.077 \pm 0.097$ \\
\hline Myristoleic acid & $0.587 \pm 0.794$ \\
\hline Palmitic acid & $0.577 \pm 0.544$ \\
\hline Heptadecanoic acid & $0.026 \pm 0.038$ \\
\hline Palmitoleic acid & $8.134 \pm 8.914$ \\
\hline Oleic acid & $2.372 \pm 2.930$ \\
\hline Stearic acid & $0.082 \pm 0.114$ \\
\hline Linoleic acid & $0.066 \pm 0.077$ \\
\hline Linolenic acid & $0.001 \pm 0.001$ \\
\hline Euric acid & $0.603 \pm 0.836$ \\
\hline Eicosatrinoic acid & $0.054 \pm 0.001$ \\
\hline Arachidonic acid & $0.053 \pm 0.090$ \\
\hline Lignoceric acid & $0.002 \pm 0.001$ \\
\hline Docosadinoic acid & $0.028 \pm 0.001$ \\
\hline Aracidic acid & $0.131 \pm 0.097$ \\
\hline Eicosenoic Acid & $0.019 \pm 0.001$ \\
\hline Eicopentanoic acid & $0.001 \pm 0.001$ \\
\hline Nervonic acid & $0.006 \pm 0.005$ \\
\hline $\begin{array}{c}\text { cis-5,8,11,14,17 } \\
\text { Eicopentanoic }\end{array}$ & $0.010 \pm 0.001$ \\
\hline Butiric ME & $84.887 \pm 15.906$ \\
\hline Undecanoid & $0.002 \pm 0.001$ \\
\hline cis-10 Pentadecanoid & $0.830 \pm 1.396$ \\
\hline Elaidic & $0.031 \pm 0.037$ \\
\hline Linolelaidic & $0.017 \pm 0.025$ \\
\hline Gama Linolenic & $0.977 \pm 1.354$ \\
\hline Behenic & $0.008 \pm 0.009$ \\
\hline cis-11, 14 Eicosadieoic & $0.062 \pm 0.086$ \\
\hline Tricosanoic & $0.008 \pm 0.006$ \\
\hline cis-10 Heptadecanoid & $0.034 \pm 0.044$ \\
\hline cis- $8,11,14$ Eicosatrionic & $0.242 \pm 0.210$ \\
\hline cis-11, 14, 17 Eicosatrionic & $0.081 \pm 0.006$ \\
\hline cis-13, 16 Docosadionic & $0.234 \pm 0.001$ \\
\hline
\end{tabular}


While the results of the analysis of the PAH compound profiles are presented in Table 2 below,

Table 2. The PAH compound profiles

\begin{tabular}{|c|c|}
\hline PAHs & Concentration (ppm) \pm SD \\
\hline Naphtalene & $0.097 \pm 0.006$ \\
\hline Acenaphthene & $0.050 \pm 0.001$ \\
\hline Phenentrene & $0.033 \pm 0.001$ \\
\hline Fluorantene & $0.077 \pm 0.006$ \\
\hline Pyrene & $11.978 \pm 2.026$ \\
\hline
\end{tabular}

Palmitic acid (C16: 0) and stearic acid (C18: 0) were found to be very excessive in content in different types of fresh fish or shellfish, and would increase in content after smoking, as reported [20], that increased palmitic acid content (C16: 0) and stearic acid (C18: 0) fresh sturgeon fish from $17.70 \%$ to $27.52 \%$, and from $7.49 \%$ to $13.63 \%$ after smoking. [21] also reported an increase in the percentage of C16: 0 fatty acids in smoked sardine fish fillets. On the contrary, [22] and [23], which reported that there was no significant effect $(\mathrm{P}>0.05)$ of the fumigation process on these fatty acid changes.

\section{CONCLUSION}

The results of the research have shown that the amino acid profile of smoked pokea clam shells is quite diverse, and the profile of PAH compounds can be categorized as weak group PAHs.

\section{ACKNOWLEDGMENT}

A big thank you to the Directorate of Research and Community Service (DRPM) Kemenristekditki for funding this research program, also to the Research and Community Service Institute (LPPM) of Halu Oleo University for facilitating research activities, Pu'uwanggudu Village Government District Asera, Konawe Utara Regency, as well as partners for processing smoked pokea shells in Pu'uwanggudu Village.

\section{REFERENCES}

[1] Balcázar JL, Blas I, Ruiz-Zarzuela I, Cunningham D, Vendrell D, Múzquiz JL. 2006. The role of probiotics in aquaculture. Vet. Microbiol. 114:173-186.

[2] Blunt JW, Copp BR, Munro MHG, Northcote PT, Prinsep MR. 2006. Marine natural products. Nat. Prod. Rep. 23:26-78.

[3] Bahtiar. 2005. Kajian populasi pokea (Batissa violacea celebensis Martens, 1897) di Sungai Pohara Kendari Sulawesi Tenggara [tesis]. Bogor: Program Pascasarjana, Institut Pertanian Bogor.

[4] Swastawati, F. 2004. The effect of smoking duration on the quality and DHA composition of milkfish
Chanos chanos F, J. of Coastal Develop., 3: 137142.

[5] Sinclair, A.J., Oon K.S., Lim L., Li D. and Mann N.J. 1998. The $\omega-3$ fatty acid content of canned, smoked and fresh in Australia, Aust. J. Nutr. Diet. 55: 116-120.

[6] Basak, S., G.F. Sengor and F.T. Karakoc. 2010. The detection of potential carcinogenic PAH using procedure in two different smoked, case study: Istanbul/Turkey, Turkish J. of Fisheries and Aquatic Sci., 10: 351-355.

[7] Koral, S., S. Kose and B. Tufan. 2010. The effect of storage on the chemical and sensorial quality of hot smoked Atlantic bonito (Sarda sarda, Bloch, 1838) packed in aluminium foil, Turkish J. of Fisheries Sci., 10: 439-443

[8] Kumolu-Johnson, C.A., N.F. Aladetohun and P.E. Ndimele. 2010. The effect of smoking on the nutritional qualities and shelf-life of Clarias gariepinus (Burchell 1822), African J. of Biotechnology, 9 (1): 073-076.

[9] Varlet, V., T. Serot, C. Knockaert, J. Comet, M. Cardinal, F. Monteau, B. Le Bizec and C. Prost. 2007. Organoleptic characterization and PAH content of salmon (Salmo salar) fillets smoked according to four industrial smoking techniques, $J$. of the Sci. of Food and Agric., 87 (5): 847-854.

[10] Isamu, K.I., Ahmad Mustafa and Fajriah. 2016. Karakteristik Kerang Pokea (Batissa violacea Celebensis Martens 1897) Asap Khas Sulawesi Tenggara. Proceeding Seminar Nasional FKPTTPI. Jambi. pp. 11-16.

[11] Stephen, M.L., Jeya Shakila R., Jeyasekaran G. and Sukumar D. 2010. Effect of different types of heat processing on chemical changes in tuna, J. Food Sci. Tech., 47 (2): 174-181.

[12] Palm, L.M.N., Deric C., Philip O.Y., Winston J.Q., Mordecai A.G. and Albert D. 2011. Characterization of polycyclic aromatic hydrocarbons (PAHs) present in smoked fish from Ghana, Advanced J. of Food Sci. and Tech., 3 (5): 332-338.

[13] Olabemiwo, O.M., A.O. Alade, A.C. Tella and G.O. Adediran. 2011. Assesment of polycyclic aromatic hydrocarbons content in smoked $C$. gariepinus and $T$. guineensis fish species available in Western Nigeria, International $J$. of Basic \& App. Sci., 11 (2): 135-150.

[14] Duedahl-Olesen L, Christensen JH, Højgård A, Granby K, Timm-Heinrich M. 2010. Influence of smoking parameters on the concentration of polycyclic aromatic hydrocarbons (PAHs) in Danish smoked fish. Food Additives and Contaminants, 27(9): 1294-1305.

[15] Joiris CR, Moatemri L, Holsbeek L. 1997. Mercury and polychlorinated biphenyls in 
zooplankton and shrimp from Barents Sea and the Spitsberg area. Bulletin Environmental Contamination Toxicology, 59 (47): 2-8.

[16] Svobodova Z, Dusek L, Hejtmanek M, Vykusova B, Smid R. 1999. Bioaccumulation of mercury in various fish spesies from Orlik and Kamyk water reservoirs in the Czech Republik. Ecotoxicology Environmental Safety 43 (2): 3140.

[17] Silva BO, Adetunde OT, Oluseyi TO, Olayinka KO, Alo BI. 2011. Effect of method of smoking on the levels of polycyclic aromatic hydrocarbons (PAHs) in some localy consumed fished in Nigeria. African Journal of Food Science 5 (7): 384-391.

[18] Sengor GF, Ozden O, Erkan N, Tuter M, Aksoy HA. 2003. Fatty acid compositions of flathead grey mullet (Mugil caphalus L., 1758) fillet, raw and beeswaxed caviar oils. Turkish Journal Fisheries Aquatic Science 3: 93-96.

[19] Hedayatifard M \& Moeini S. 2007. Loss of omega3 fatty acid of sturgeon Acipenser stellatus during cold storage. International Jurnal Agriculture Biology 9: 598-601.

[20] Kaya Y, Turan H, Erdem ME. 2008. Fatty acid and amino acid composition of raw and hot smoked sturgeon (Huso huso L. 1758). International Journal of Food Science and Nutrition 59 (7-8): 635-642.

[21] Beltran A \& Moral A. 1991. Changes in fatty acid composition of fresh and frozen sardine (Sardina pilchardus, W.) during smoking. Food Chemicals 42: 99-109.
[22] Asiedu MS, Julsham K, Lie Ø. 1991. Effect of local processing methods (cooking, frying and smoking) on the three fish spesies from Ghana: Part I. proximate composition, fatty acids, minerals, trace elements and vitamins. Food Chemicals 40(3): 309-321.

[23] Vasiliadou S, Ambrosiadis I, Vareltzis K, Fletouris D, Gavriilidou I. 2005. Effect of smoking on quality parameters of farmed gilthead sea bream (Sparus aurata L.) and sensory attributes of the smoked product. European Food Research Technology 2217: 232-236.

[24] Little SO, Armstrong SG, Bergan JG. 2000. Factors affecting stability and nutritive value of fatty acids. Culinary Practical 2: 427-437.

[25] Otles S \& Sengor G. 2005. Effect of various technological processes on the fatty acid composition of mussel (Mytilus galloprovincialis L.). International Journal Food Engineering 1 (3): 1-7.

[26] Visciano P, Monia P, Maurizio M, Michele A. 2009. Selected polycyclic aromatic hydrocarbons in smoked tuna, swordfish and Atlantic salmon fillets. International Journal of Food Science \& Technology 44: 2028-2032.

[27] Sprovieri M, Feo ML, Prevedello L. 2007. Heavy metal, polycyclic aromatic hydrocarbons and polychlorinated biphenyls in surface sediments of the Naples harbor (southern Italy). Chemosphere 67: 998-1009.

[28] Lijinsky W. 1991. The formation and occurrence of polynuclear aromatic hydrocarbons associated with food. Mutat Research 259 (2): 51-61. 